\title{
Translation and Arabicization Methods of English Scientific and Technical Terms into Arabic
}

\author{
Rokiah Awang \\ Translation Studies\& Interpreting Section, School of Humanities, Universiti Sains \\ Malaysia (USM), Pulau Pinang, Malaysia, arokiah@usm.my
}

Ghada Salman

Translation Studies\&Interpreting Section, School of Humanities

Universiti Sains Malaysia (USM), Pulau Pinang, Malaysia

\begin{abstract}
Due to linguistic differences among languages, rendering new concepts embodied in new terms has always been a challenging issue in translation. English has become the medium of science and technology. Therefore, it has dominance over other languages of the world. Technical terms and concepts are translated mainly from English to other languages such as the Arabic language. Because of the foreignness and unfamiliarity of these terms in Arabic, the Arabic Language Academy[majma' al-lughati al-arabiyah] has always endeavoured to coin native terms in order to domesticate and naturalizeforeign terminology into Arabic. To accomplish this goal, translation strategies, as well as Arabic word-formation techniques such as derivation and composition have been employed by the academy. Among Arabicization methods isoutright phonetic borrowing of the English term via transliteration into Arabic sounds and characters. Another form of borrowing is calque (loan translation). This translation and Arabicization method has also been used by the academy in its terminology work. The aim of this research is to identify strategies of translation and Arabicization used by the academy in its terminology work. Accordingly, a descriptive and comparative analysis of ten English scientific and technical terms with their translational and Arabicized equivalents were analyzed and discussed. These terms were translated and Arabicized by the Arabic Language Academy of Cairo (Cairo ALA), which adopted various translation and Arabicization approaches to introduce and assimilate these terms into Arabic. Translation methods included borrowing (loan word), loan translation (calque) and literal translation (word-for-word). Arabicization methods included outright phonetic borrowing, loan translation, derivation, and composition. Findings suggested that Cairo ALA has appropriately applied methods of translation, as well as techniques of Arabicization in its efforts to delimit the foreignness of English terms. Accordingly, these terms were properly domesticated into

Arabic.

Keywords: Translation, Arabicization, word-formation methods, terminology, foreignization. Cite as: Awang,R.\& Salman, G. (2017). Translation and Arabicization Methods of English Scientific and Technical Terms into Arabic. Arab World English Journal for Translation \& Literary Studies, 1(2). DOI:http://dx.doi.org/10.24093/awejtls/vol1no2.8
\end{abstract}


AWEJ for translation \& Literary Studies volume, 1 Number 2, May 2017

Translation and Arabicization Methods of English Scientific

Awang \& Salman

\section{Introduction}

The term Arabicization comes to light whenever there is a lack of translational equivalence or equivalent effect in Arabic. Word-coinage, which is a process of word-formation, usually takes place when a natural equivalent of the foreign concept or term is missing. Most often, new words of technology, i.e., scientific and technical terms, lack natural and standard equivalents in the host languages such as the Arabic language. For Pinchuck (1977) languages may suffer from gaps at the lexical level, and most likely, "one language will have no words for a concept expressed in the second language" (p. 53).Catford (1967) has earlier emphasized the difficulty of establishing translation equivalence between lexical items, especially when technical terms are concerned. Therefore, it is quite difficult to create absolute translation equivalence between technical and scientific terms in two different languages such as English and Arabic. Accordingly, the gap may be filled by a term borrowed from the source language or by the creation of a new term in the target language. To be natural and domesticated for native Arabs, scientific and technical terminology has been assimilated into the Arabic language through translation and Arabicization methods (Al-Asal\&Smadi, 2012). In the context of this paper, translation methods include borrowing (loan word), literal translation (word-for-word) and loan translation (calque). Arabicization methods include phonetic borrowing via transliteration, which is generally referred to as Arabicization (at-ta'rib) by many scholars of Arabic, as well as wordformation techniques such as derivation and composition. Therefore, the researchers believe that the concept of Arabicization refers to the application of various word-formation processes in Arabic including phonetic borrowing via transliteration. Accordingly, when a foreign term is Arabicized, it is either coined in accordance with word-formation rules of Arabic and/or phonetically borrowed from the source language.

The concept of Arabicization is differently approached by Arab linguists and scholars. According to Al-Asal \& Smadi (2012), Arabicization is used to refer to a process of transliteration, where a foreign term is merely transliterated in conformity with the Arabic phonological and graphological systems. Therefore, when a certain English technical term is 'Arabi- cized', it means that "it is linguistically borrowed from English and used in Arabic with some modification, e.g., 'filtration'(faltarah) or without modification, e.g., 'filter'(filtar)" (p. 22). In the same vein, Ahmed (2011, p. 469) believes that Arabicization is an adopted and already implemented strategy to introduce new concepts into Arabic. It is "the process of translating foreign terms using Arabic forms". For instance, the English philosophy, drachma and asphalt are Arabicized into falsafah, dirham and is falt, respectively. Arab scholars often refer to such transference as phonetic borrowing (Darwish 2009).English-Arabic examples include the English radar intoرادر, which is phonetically transferred into Arabic through a process called 'transliteration' or 'transcription'. Here, the phonetic properties of the source language term are directly transferred with or without modification into the target language. Therefore, Arabicization, in its narrowest sense, entails mere transliteration of a foreign term according to Arabic sounds and characters (Khulusi, 1982).

With respect to institutional Arabicization efforts in the Arab region, Arabic Language Academies (ALAs), which are language agencies based in a number of Arab countries, have shouldered the responsibility of maintaining the integrity of the Arabic language as the academies' main objective. These academies have also strived to fulfill the needs of science, arts, and modern civilization. Therefore, they have made extraordinary efforts to produce 
AWEJ for translation \& Literary Studies volume, 1 Number 2, May 2017

Translation and Arabicization Methods of English Scientific

Awang \& Salman

comprehensive dictionaries, publish journals of linguistic research and verify the richness of Arabic cultural heritage, as well as explore new horizons for its progress and modernization. Arabicization of foreign scientific and technical terms تعريب المصطلحات العلمية والفنية]ta'rib almustalahat al-ilmiyahwal-faniyah] has been one of its main tasks since their establishment in Damascus in 1919, in Cairo 1932, in Baghdad 1974, in Amman 1976, andBayt al-Hikma of Tunisia 'the House of wisdom' in 1983 (Darwish, 2009).It is worth mentioning that these Arabic language academies have so far issued several resolutions with far-reaching impact on the development of scientific terminology, Arabicization, phonetics, enunciation, and morphology of Arabic. These resolutions included the establishment of a library with more than 40,000 titles related to various branches of knowledge such as the Arabic language and literature, ancient and modern sciences, as well as applied arts. The Arabic Language Academy of Cairo (Cairo ALA) publishes a bi-annual journal. The journal includes the academy's conference proceedings, books and research papers.In addition, Cairo ALA has so far issued a large collection of general and specialized Arabic language dictionaries in the fields of linguistics, literature, grammar, eloquence, morphology, philosophy, history, geography, psychology, life sciences, arts, medicine, mathematics, and civilization (Arabic Language Academy in Cairo).This made it possible for the Arabic language to readily accommodate life sciences, modern civilization, applied sciences, and technology. The focus of this paper is, therefore, on translation methods and Arabicization techniques, which are employed by Cairo ALA in its translation and Arabicization terminology work.

\section{Terminology Work in Arabic}

Terminology is defined as the collection of terms that embody concepts of a certain field (Felber, 1984,as cited in Bahumaid, 2010).In the field of science and technology, terminology is important to designate innovations and new products. In the context of Arabic, the creation of a stable, standardized terminology in various subject areas assumes a special significance in the quest of Arab institutions to accomplish their much-aspired goal of Arabicization. However, crucial problematic aspects related to terminology making in Arabic are an issue of concern today. These aspects involve the existence of a multiplicity of corresponding forms for one term, the conceptual imprecision, the vagueness and ambiguity of many such forms, as well as the inconsistency in their usage. According to Darwish (2009), terminology management and methodology in Arabic has certain thorny characteristics:

- Different bodies and entities or even individuals focus on Arabic terminology, each of which has its own experience, skill and capability. Therefore, they work in different situations with different aims. One of the problems of the individual work is that it is not authorized and entrusted. Organizational activities are done on large scales and enjoy higher popularity. However, they are not suitable in practice.

- Terminologies are limited into some volumes of glossaries and dictionaries or even books published by some organizations or language academies. Hence, a few hundreds of terms are translated or transliterated and may not cover every new term.

- Since terminologies are compiled for different fields of studies, some disciplines are perhaps more focused on leaving other majors unbalanced. Therefore, the compiled lists do not necessarily cover all disciplines of knowledge. 
AWEJ for translation \& Literary Studies volume, 1 Number 2, May 2017

Translation and Arabicization Methods of English Scientific

Awang \& Salman

- To compile lists of terms, compilers may choose various methods or approaches of translation and Arabicization. A number of these methods are in accordance with the regulations of the main Arabic Language Academy in Cairo, some other methods are not. Since word-formation techniques are different, each of these organizations or academies tries to adopt one of these techniques more frequently compared to the other. These techniques are mainly derivation, compounding, loan translation, and Arabicization (pp. 112-113).

Based on a translational approach ,the techniques that stick to the target language norms somehow represent the 'domestication' translation strategy, and those that are inspired by the source language norms lean towards the 'foreignization' strategy of translation. As for Arabic, when foreign terms are Arabicized, they should be domesticated and naturalized through the application of inherent morphological and derivational rules of the Arabic language so that the impact of foreignization, mainly from English on Arabic, is delimited. Therefore, inherent Arabic word-formation methods such as derivation, composition and compounding should be applied to coin appropriate Arabicized terms. Otherwise, outright lexical borrowing, which is a mere transliteration of English sounds and letters, can help accelerate foreignization of Arabic. Borrowing usually takes place to fill in missing lexical gaps if native, straightforward or partial Arabicized equivalents are not available.

\section{General Methods of Word-formation in Arabic}

To adopt or coin new terms, every language utilizes its own approaches and strategies. They either expand their vocabulary treasure based on their own existing language capabilities or based on borrowing from other languages (Darwish, 2009). The most important methods of word-formation that are used in Arabic are as follows:

\section{Arabicizationor Lexical borrowing (at-ta'ribeتعريب)}

In the perspective of many Arab linguists, Arabicization refers to phonetic borrowing via transliteration and/or transcription. According to Darwish (2009), outright phonetic borrowing is the process through which "the phonetic properties of the source language technical terms are rendered with modification to suit Arabic pronunciation methods" (pp.113-114).However, Darwish believes that this definition has ignored some points. For example, by referring to 'transliteration' and 'transcription' of terms, it failed to notice that there is no unified standard system of transliteration and transcription depicting foreign terms in Arabic. Therefore, it would result in the existence of "different orthographic renditions of such terms influenced by the phonologies of different Arabic dialects and foreign languages". For example, the English prefix [hydro-] is differently rendered as 'هيدرو' [ هايدرو' [hidro-]and' [hydro-].Accordingly, Arab linguists and terminology makers reaffirm that there is no clear methodology or standardized guidelines for assimilating English terms into Arabic. Arabicization of foreign terms is then, as Darwish suggests, subject to neologizers' personal preferences. Ya'qub (1986, as cited in Darwish, 2009) has earlier warned that excessive use of lexical borrowing via transliterating and transcribing English letters and sounds into Arabic would jeopardize the foundation of the Arabic language and could make it unintelligible and unreadable. Although lexical borrowing is an inevitable phenomenon which exists in every language, it has to be exercised under 
AWEJ for translation \& Literary Studies volume, 1 Number 2, May 2017

Translation and Arabicization Methods of English Scientific

Awang \& Salman

certainlimitations and restrictions. Instead, intrinsic methods of word-formation in Arabic should be applied, and minimal usage of lexical borrowing is preferable. Otherwise, "Arabic could end up as a Maltese: a mixture of several foreign languages expressed in more or less an Arabic structure".

With respect to the acceptability of Arabicized terms proposed by Arabic language academies, Al-Haq and Al-Essa (2016) conclude that attitudes towards Arabicized business terms, which were translated and published by the Jordan Academy of Arabic, were generally positive. This gives useful recommendations for terminology makers in ALAs in order to come up with appropriate and generally accepted Arabicized terms. In another related research paper, Al-Asal\& Smadi (2012) measured frequency rates, as well as popularity of word-formation techniques in Arabic such as derivation, compounding, loan translation, and semantic extension used in lectures given by faculty members of the Jordan University of Science and Technology compared to their colleagues at the University of Damascus. Findings suggested that more cooperation and coordination between the Jordan Academy of Arabic and the Damascus Academy of Arabic should be planned so that unified and standardized scientific and technical terms are disseminated throughout all Arab universities in the region.Hawamdeh (2004) carried out a study on the acceptability of Arabicization as a word-formation method in coining Arabicized weather terms. Findings revealed thatthe pamphlet of weather terms, which is published by the Jordan Academy of Arabic, is not commonly used in translation. Translators consult different specialized dictionaries and depend on their general knowledge in translating weather terms from English into Arabic.

\section{Semantic/Pragmatic Modification of Existing Arabic Terms (المجاز al-majaz)}

According to this word-formation technique, foreign words are translated into Arabic by using Arabic equivalents. Old Arabic words appear with new meanings. However, this technique has its pitfalls as literal translation does not always succeed in rendering the terms contextually correct. For instance, 'dead room' in acoustics is rendered as (غرفه مينة)'ghurfahmayyitah' instead of (غرفه كاتمه) 'ghurfahkatima' (Darwish, 2009, p.114).

\section{Derivation (الاشتقاق قal-ishtiqaq)}

Derivation is one of the oldest techniques of word-formation, which rests on inherent Arabic patterns and models. Darwish (2009)classifies derivations of Arabic into three types: minor derivation, major derivation and greater derivation (p. 115).

\section{Minor Derivation( الاثتنقاق الصغير) [al-ishtiqaq al-sagheer]}

Arabic words usually consist of roots. Minor derivation refers to a word-formation process through which new words are formed from one root in conformity with standard Arabic patterns of subject, verb, object, adjective, etc. as in the following example. The Arabic trilateral root كَّكَ تَبَ

\section{Table 1. Examples of minor derivation}

\begin{tabular}{|l|l|l|}
\hline Root & Transliteration & Translation \\
\hline Sت & Kataba & He wrote \\
\hline
\end{tabular}

Arab World English Journal for Translation \& Literary Studies eISSN: 2550-1542 | www.awej-tls.org 
AWEJ for translation \& Literary Studies volume, 1 Number 2, May 2017

Translation and Arabicization Methods of English Scientific

Awang \& Salman

\begin{tabular}{|c|c|c|}
\hline يكتبُ & Yaktubu & He writes \\
\hline كاتب & Katib & Writer \\
\hline مكتوب & Maktub & Written/letter \\
\hline مكتب & Maktab & Office, desk \\
\hline مكتبة & Maktabah & Bookshop, library and so on \\
\hline
\end{tabular}

Major Derivation (الاشتقاق الكبير) [al-ishtiqaq al-kabeer]

It is defined as the creation of new words from existing 3-letter words by conversion and rearrangement of letters. For example, the word سبر [sabara] سَ بَ رَ following words:

Table 2.Examples of major derivation

\begin{tabular}{|c|c|c|}
\hline Word & Transliteration & Meaning \\
\hline برس & Barasa & $\begin{array}{l}\text { To be hard on one's opponent, barrasa al-arad is } \\
\text { to smoothen the ground, al-baras is cotton }\end{array}$ \\
\hline 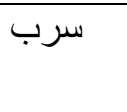 & Saraba & $\begin{array}{l}\text { To go away. (السرب); "as-sarb" is a flock of birds/ } \\
\text { herd of animals; (سرب) "sariba" is to leak }\end{array}$ \\
\hline رسب & Rasaba & To fail, to precipitate \\
\hline بسر & Basara & To frown, to squeeze a pimple, etc. \\
\hline 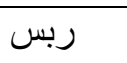 & Rabasa & To hit with the hand, to interlace, to weaken, etc. \\
\hline سبر & Sabara & To probe \\
\hline
\end{tabular}

\section{Greater Derivation (الاشتقاق الأكبر) [al-ishtiqaq al-akbar]}

It is the coinage of new words by substituting one phoneme by another of the same

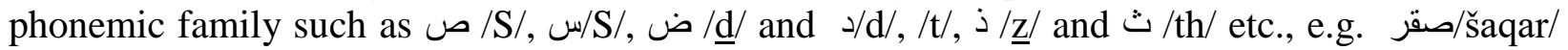
and سقر/saqar/.All of the above word-creation methods use the same roots of the Arabic words to make new words. The derived words are made from one root. Therefore, derivation is considered one of the frequent methods in the formation of scientific and technical terms in Arabic.

\section{Compounding (النحت an-naht)}

Compounding refers to the coinage of new words by merging two or more words to signify their meaning. Compounding has three kinds: blending, merging and affixation. For example, Abdullah (عبدالله) is a blended word, where the Arabic Abdu meaning 'servant' in English + the Arabic Allah are blended into Abdullah. 'Abdullah' is used as a proper name in Arabic. Another example is the Arabic scientific term [kahrumaghnatisi_كهرومغناطيسي] for the English termelectromagneti. It is coined via blending from two words: electric [kahrabai, كهربائي] + 
magnetic [maghnatisi, مغناطيسي]. Examples of merging include the Arabic hawqala (حوقيس), which stands for la howlawa la qowataillabillah (بسملة)( لا حول و لا قوة الا بالله) and besmellah besmilLah (بسم الله). Another example is the merged phrase hamdala (حمدلة). It means to say al-hamduliLahi ('praise be to God'), which stands for alhamdolellah (الحمد لله). The Arabic (لاسلهي) la siasi, (برمائي) bar ma'i, and (رأسمالي) ra'smali, which refer to the English apolitical, amphibious and capitalist, respectively are examples of affixation (Darwish, 2009: 116).

\section{Composition (التركيب) at-tarkib)}

Based on this method of word-formation, Arabic words are combined with "foreign affixes and suffixes or Arabic affixes or prefixes are combined with foreign words" (Darwish, 2009). Generally, Arab translators and writers, who are in contact with foreign cultures and civilizations, make deft use of composition as a word-formation technique in the Arabicization process.

Table 3.Examples of composition

\begin{tabular}{|c|c|c|}
\hline Arabicized Term & Transliteration & English Term \\
\hline ثانى اكسيد الكربون النتريكى & Thaniuksid al-karbun & Carbon dioxide \\
\hline حمبد حمضى & Hamd an-natrik & Nitric acid \\
\hline
\end{tabular}

\section{Arabic Language Academies' (ALAs) Terminology Work of Arabicization}

The role of Arabic Language Academies (ALAs) has been a key issue in terminology studies of the Arabic language to which researchers of linguistics and terminology have paid significant attention. Darwish (2009) lists and discusses the agencies or academies of Arabic that deal with Arabicized terminology. He also debates translation and Arabicization methods they apply in their terminological work regarding the creation of new terms. In the 20th century, several Arabic Language Academies were founded in the Arab world modeled from the French Academy. Their objectives were basically to maintain the "purity" of Arabic and to "modernize" this language to be able to deal with scientific and technological advancements taking place in the western countries. To attain the desired goal, these academies have commenced to issue terminology books, dictionaries and pamphlets in many fields of knowledge. At the same time, many organizations have undertaken the mission of engaging with such terminology work to help the academies meet their immediate needs such as the Arabicization Bureau in Rabat/Morocco. However, the work of these agencies has been characteristically disconcerted and uncoordinated and, to a certain degree, driven by personal and political interests, which is another outlet for regional differences and individual ambitions. Each agency claims its method to be the best and its terminologies to be the valid and most appropriate ones. In fact, these agencies have competed in a marathon of compiling terminologies. The result was the emergence of duplicated works of terminology-formation and a multiplication of redundant terms. In the 
AWEJ for translation \& Literary Studies volume, 1 Number 2, May 2017

Translation and Arabicization Methods of English Scientific

Awang \& Salman

same vein, Abdelhay, Eljak, Mugaddam, \&Makoni (2016) have reiterated that "Arabic language academies emerged as decolonising institutions in a context of struggle to fix the 'image' of Arabic through specific textual practices of representation" (p. 1).

It is perhaps worth to mention here that the first Arabic language academies, which were established in the Arab world, include the Arabic Language Academy of Damascus (1919), the Arabic Language Academy of Cairo (1932), the Iraqi Scientific Academy (1974), the Arabic Language Academy of Jordan (1976), and Bayt al-Hikma of Tunisia, the House of Wisdom (1983). Other academies were also established later in a number of Arab capitals. They are: the Supreme Council of the Arabic language in Algeria (1996), the Lebanese Academy of Sciences, officially known by its French name 'Académie des Sciences du Liban' (2007), the Academy of the Arabic Language, which is an institute for the study and research of Arabic in Palestine (2007), the Arabic Language Academy in Khartoum/Sudan, and the Libyan Arabic Language Academy. In 2013, Cairo ALA was awarded the 2013 KFIP (King Faisal International Prize) for Arabic language and literature. Therefore, the authors of this paper have chosen this academy's glossary of Arabicized technical and scientific terms for this study. These terms were Arabicized and issued by the academy in its periodic terminology pamphlet: A Collection of Scientific and Technical TermsVolume 42, Cairo 2002. Moreover, Cairo ALA, which was founded in 1932, has been so far considered as an authorized official organization that commands considerable influence and respect in the Arab World (Aziz, 1983).

\section{Methodology}

This research paper is a comparative and descriptive study often Arabicized scientific and technical terms. The study limits itself to ten terms as samples of the huge terminology corpus of the academy, which includes (2335) Arabicized terms. These terms are included in Cairo ALA's collection of scientific and technical terms entitled 'A Collection of Scientific and Technical Terms Volume 42, Cairo 2002'. The content of Cairo ALA's collection of English-Arabic scientific and technical terminology includes English (ST) - Arabic (TT) pairs of translational and Arabicized terminologies classified into 11 categories covering various branches of knowledge. They are: 1) terms of physics, 2) terms of oil, 3) terms of biology, 4) terms of civilization, 5) terms of medical sciences, 6) terms of literature, 7) terms of computer, 8) terms of geology, 9) terms of engineering, 10) terms of jurisprudence, and 11) terms of mathematics.

Methods of translation, as well as Arabicization techniques, in other words, wordformation processes used to coin Arabicized equivalents for the English terms were examined and analyzed (Table 1). Following a descriptive and comparative method, the researchers described and compared English (SL) - Arabic (TL) pairs of terms. Obtained data were interpreted accordingly in terms of frequency rates of use of translation and Arabicization methods of coining Arabicized scientific and technical terms. These terms are randomly selected from Cairo ALA's given collection. First, the researchers identified methods used in translating and Arabicizing the sample terms. Second, they investigated the frequency of use of various translation and Arabicization methods to identify the most frequently used method in the Arabicization work. Justification of findings is provided. The investigation of the Arabicization 
AWEJ for translation \& Literary Studies volume, 1 Number 2, May 2017

Translation and Arabicization Methods of English Scientific

Awang \& Salman

methods includes main methods of word-formation techniques in Arabic. They are: outright phonetic borrowing via transliteration, as well as derivation and compounding based on Darwish's (2009) linguistic classification of Arabicization methods. Based on Vinay and Darbelnet's (1995) taxonomy of translation methods, the three translation procedures of direct translation strategy are located and discussed in the analysis. They are: borrowing (loan word), calque (loan translation) and literal translation (word-for-word). As each of the Arabic language academies has its own translation and Arabicization methods, the analysis focuses on Cairo ALA's work methodology in translation and Arabicization of foreign terminology.

Table 4. Data analysis of Cairo ALA's (2002) translation \& Arabicization methods

\begin{tabular}{|c|c|c|c|}
\hline English Term & Arabicized Term & Translation Method & Arabicization Method \\
\hline \multirow[b]{2}{*}{ internet } & $\begin{array}{c}\text { الإنترنت } \\
\text { [al-internet] }\end{array}$ & $\begin{array}{c}\text { Phonetic Borrowing via } \\
\text { Transliteration }\end{array}$ & $\begin{array}{c}\text { الاستعارة اللفظية } \\
\text { [al-isti'arah al- } \\
\text { lafdhiyah] }\end{array}$ \\
\hline & $\begin{array}{c}\text { الشبكة الدولية } \\
\text { [al-shabakah al- } \\
\text { dawliyah] }\end{array}$ & $\begin{array}{l}\text { Loan Translation } \\
\text { (Calque) }\end{array}$ & $\begin{array}{c}\text { الاستعارة الدلالية } \\
\text { [al-isti'arah al-dalaliyah] } \\
+ \\
\text { Composition التركيب] } \\
\text { [at-tarkib] }\end{array}$ \\
\hline Motherboard & $\begin{array}{c}\text { [al-lawha al-um] } \\
\text { [اللوحة الأم }\end{array}$ & $\begin{array}{l}\text { Loan Translation } \\
\text { (Calque) }\end{array}$ & $\begin{array}{c}\text { الاستعارة الدلالية } \\
\text { [al-isti'arah al-dalaliyah] } \\
+ \\
\text { Composition } \\
\text { [at-tarkib] }\end{array}$ \\
\hline Node & $\begin{array}{c}\text { عقده } \\
\text { [uqdah] }\end{array}$ & Literal Translation & $\begin{array}{c}\text { Derivation } \\
\text { الاثنقاق }[\text { al-ishtiqaq] }\end{array}$ \\
\hline Polygon & [mudhala'] & Literal Translation & $\begin{array}{c}\text { Derivation } \\
\text { الاشتقاق [al-ishtiqaq] }\end{array}$ \\
\hline $\begin{array}{l}\text { RGB ( red, green, } \\
\text { blue) }\end{array}$ & $\begin{array}{c}\text { أحمر، أخضر، أزرق } \\
\text { [ahmar, akhdhar, } \\
\text { azraq] }\end{array}$ & Literal Translation & $\begin{array}{l}\text { Composition } \\
\text { التركيب }\end{array}$ \\
\hline $\begin{array}{c}\mathrm{TCP} / \mathrm{IP}= \\
\text { Transmission } \\
\text { control } \\
\text { protocol/internet } \\
\text { protocol }\end{array}$ & $\begin{array}{c}\text { بروتوكول التحكَّم فى الإرسال } \\
\text { [protocol al-tahakum } \\
\text { fi al-irsal] }\end{array}$ & $\begin{array}{c}\text { Phonetic Borrowing via } \\
\text { Transliteration } \\
\text { (protocol is a loan word } \\
\text { in Arabic) } \\
+ \\
\text { Literal Translation }\end{array}$ & $\begin{array}{c}\text { التركيب الاستعارة اللفظية } \\
\text { [al-isti'arah al-lafdhiyah] } \\
+ \\
\text { Composition } \\
\text { [at-tarkib] }\end{array}$ \\
\hline $\begin{array}{c}\text { WORM (Write } \\
\text { Once, Read } \\
\text { Many) }\end{array}$ & [ & $\begin{array}{l}\text { Phonetic Borrowing via } \\
\text { Transliteration } \\
\text { (transliterated acronym } \\
\text { as a loan word in } \\
\text { Arabic) }\end{array}$ & $\begin{array}{c}\text { الاستعارة اللفظية } \\
\text { [al-isti'arah al- } \\
\text { lafdhiyah] }\end{array}$ \\
\hline $\begin{array}{l}\text { Barite rose }= \\
\text { barite rosette }\end{array}$ & $\begin{array}{c}\text { وردة بارِيت } \\
\text { [wardat barite] }\end{array}$ & $\begin{array}{l}\text { Phonetic Borrowing via } \\
\text { Transliteration (Barite) }\end{array}$ & $\begin{array}{c}\text { الاستعارة اللفظية } \\
\text { [al-isti'arah al-lafdhiyah] }\end{array}$ \\
\hline
\end{tabular}

Arab World English Journal for Translation \& Literary Studies 
AWEJ for translation \& Literary Studies volume, 1 Number 2, May 2017

Translation and Arabicization Methods of English Scientific

Awang \& Salman

\begin{tabular}{|c|c|c|c|}
\hline & & $\begin{array}{c}++ \\
\text { Literal Translation }\end{array}$ & $\begin{array}{c}+ \\
\text { Composition التركيب } \\
\text { [at-tarkib] }\end{array}$ \\
\hline $\begin{array}{c}\text { Biochemical } \\
\text { oxygen demand }\end{array}$ & $\begin{array}{c}\text { البيوكيمبائى الاكيجينى البئى } \\
\text { [al-matlab al-uksigini } \\
\text { al-biochemyae'] }\end{array}$ & $\begin{array}{c}\text { Phonetic Borrowing via } \\
\text { Transliteration } \\
\text { (Biochemical oxygen) } \\
+ \\
\text { Literal Translation }\end{array}$ & $\begin{array}{c}\text { الاستعارة اللفظية } \\
\text { [al-isti'arah al-lafdhiyah] } \\
+ \\
\text { Composition } \\
\text { [at-tarkib] }\end{array}$ \\
\hline Dynamo fluidal & 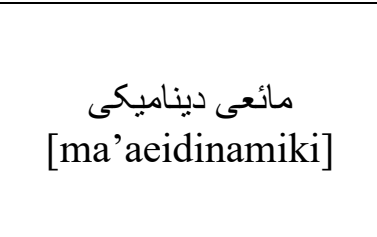 & $\begin{array}{c}\text { Phonetic Borrowing via } \\
\text { Transliteration } \\
\text { (Dynamo) } \\
+ \\
\text { Literal Translation }\end{array}$ & 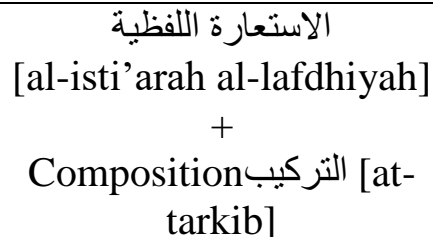 \\
\hline
\end{tabular}

\section{Data Analysis\& Findings}

Table 4 and Figure 1 illustrate the frequency rates of Cairo ALA's (2002) translation methods used to translate the examined ten terms. It is found that a combination of both methods of phonetic borrowing + literal translation is used to render four terms into Arabic. Those terms are: TCP/IP, Barite rose, Biochemical oxygen demand, and Dynamo fluidal. Phonetic borrowing and calque are used to translate two terms under each method. Two terms are phonetically borrowed and introduced into Arabic, which are 'internet' and 'WORM'. The English acronym 'WORM' is borrowed and assimilated into Arabic as an acronym (وُرم). Similarly, calque is used to translate 'internet' and 'motherboard'. The term 'motherboard' is loan-translated into Arabic, whereby the concept of this term is taken from English. Therefore, the foreign concept is borrowed and accordingly assimilated into Arabic through loan translation. It is also found that three of the examined terms, Node, Polygon, $R G B$, are translated using literal translation method.

Table 5.Frequency rates of Cairo ALA's (2002) translationmethods

\begin{tabular}{|l|l|c|c|}
\hline & \multicolumn{1}{|c|}{ Translation Method } & Frequency & Percentage \\
\hline 1. & Phonetic Borrowing via Transliteration & 2 & $18 \%$ \\
\hline 2. & Loan Translation (calque) & 2 & $18 \%$ \\
\hline 3. & Literal Translation & 3 & $27 \%$ \\
\hline 4. & Phonetic Borrowing + Literal Translation & 4 & $37 \%$ \\
\hline
\end{tabular}




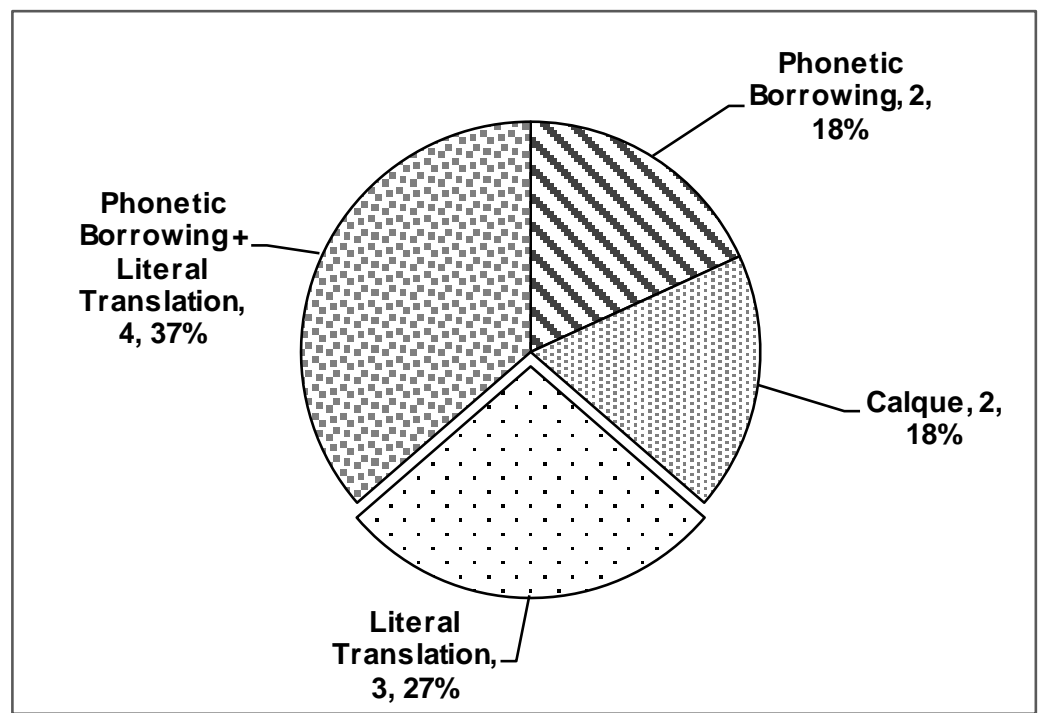

Figure 1.Frequency Rates of Translation Methods among the Examined Terms

On the other hand, various Arabicization methods are used by Cairo ALA in the Arabicization process. Table 6 and Figure 2 illustrate the frequency rates of Arabicization methods used to Arabicize the selected ten terms. Results showed that الاستعارة اللفظية [al-isti'arah al-lafdhiyah] + [at-tarkib] is the most frequently used method. Four terms are Arabicized using this method. They are: $T C P / I P=$ Transmission control protocol/internet protocol, Barite rose=barite rosette, Biochemical oxygen demand, and Dynamo fluidal. However, the least frequently used method of Arabicization is التركيب [at-tarkib]. Composition التركيب [at-tarkib] alone is used at $9 \%$. Only one term, which isRGB (red, green, blue), is formed in conformity with this word-formation method in Arabic. This term is composed of three nouns in Arabic أحمر, أخضر, أزرق). The remaining three methods are used at a similar frequency rate of $18 \%$. These methods are: الاستعارة اللفظية [al-isti'arah al-lafdhiyah], الاشتقاق [al-istiqaq] and الاستعارة الدلالية [al-isti'arah al-dalaliyah] + التركيب [at-tarkib]. The Arabicized form (الإنترنت) for the English 'internet' is phonetically borrowed from English via transliteration. Derivation الاشتقاق [alishtiqaq] is used to translate two terms. They are: Node and Polygon. Node عقده [uqdah] and

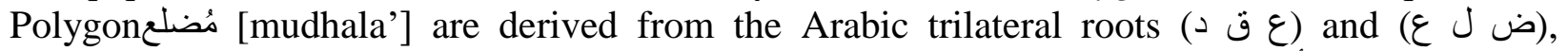

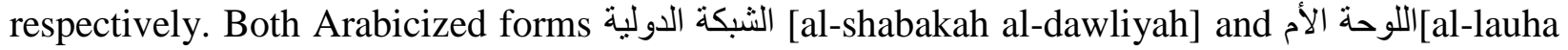
al-um] for 'motherboard' and 'internet' are loan translated.

Accordingly, two inherent word-formation methods in Arabic were applied in the Arabicization work of the examined samples of scientific and technical terms. They are derivation[الاشتقاق[al-ishtiqaq] and composition التركيب[at-tarkib]. Composition, however, is more widely used than derivation in the Arabicization process. On the other hand, الاستعارة اللفظية, [alisti'arah al-lafdhiyah] is also frequently used. However, this method does not draw upon native and inherent word-formation processes of the Arabic language. In this method, terms are phonetically transliterated from English into Arabic. Therefore, terms here do not undergo any of the processes of word formation. This can be justified by the fact that transliteration and/or transcription of foreign sounds and letters have become part of the Arabicization process, which 
AWEJ for translation \& Literary Studies volume, 1 Number 2, May 2017

Translation and Arabicization Methods of English Scientific

Awang \& Salman

is mainly carried out from Latin into Arabic alphabets because Arabic has unfortunately become a receptor language, particularly in the science and technology arena (Ahmed, 2011).

Table 6.Frequency rates of Cairo ALA's (2002) Arabicization methods

\begin{tabular}{|c|c|c|c|}
\hline & Arabicization Method & $\begin{array}{c}\text { Frequenc } \\
\mathbf{y}\end{array}$ & Percentage \\
\hline 1. & الاستعارة اللفظية][al-isti’arah al-lafdhiyah] & 2 & $18 \%$ \\
\hline 2. & [al-isti’arah al-lafdhiyah] + التركتعارة اللفظية [at-tarkib] & 4 & $37 \%$ \\
\hline 3. & التركيب + الاستعارة الدلالية [al-tarkib] [al-isti'arah al-dalaliyah] & 2 & $18 \%$ \\
\hline 4. & [al-ishtiqaq] & 2 & $18 \%$ \\
\hline 5. & |at-tarkib] التركيب & 1 & $9 \%$ \\
\hline
\end{tabular}

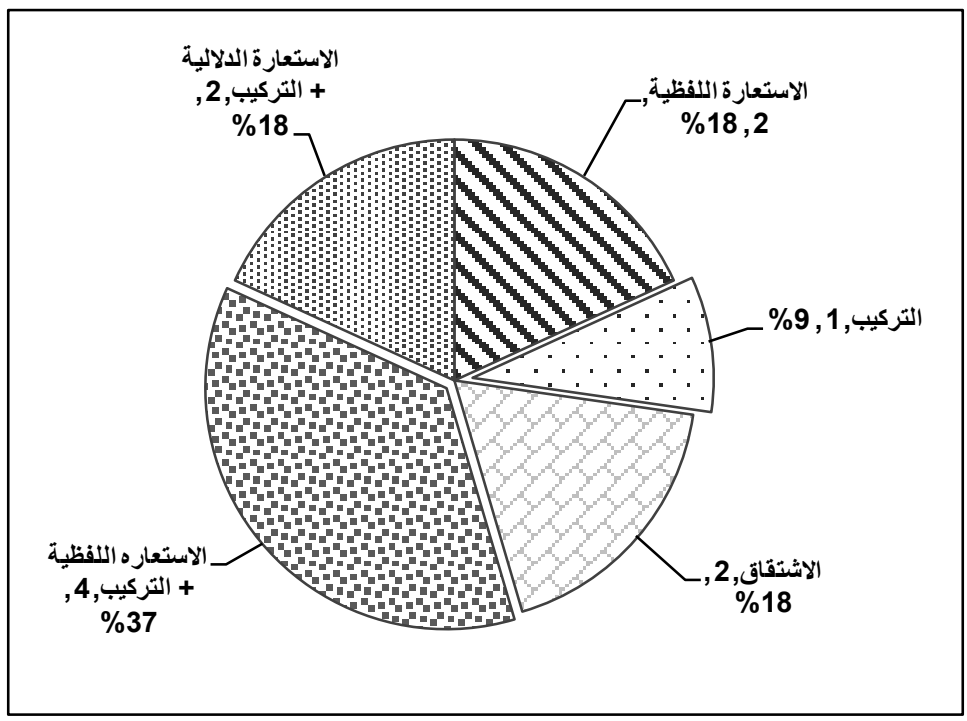

Figure 2.Frequency Rates of Arabicization Methods among the Examined Terms

\section{Discussion}

Based on the descriptive and comparative analysis of the research data, both 'literal translation' and 'composition' were the most frequently used translation and Arabicization methods. This can be justified by the fact that these terms are scientific and technical in essence and, therefore, they usually lend themselves to word-for-word (literal) translation to maintain precision and clarity of the concept, as well as its form. Moreover, technical translation aims at transmitting factual information only. Hence, technical terms should be clear and precise. Composition as a 
AWEJ for translation \& Literary Studies volume, 1 Number 2, May 2017

Translation and Arabicization Methods of English Scientific

Awang \& Salman

word-formation process in Arabic has in fact contributed the most to creating new Arabicized scientific and technical terminology mainly because of the method's flexibility in forming new Arabic words, which makes it versatile enough for translators and neologizers to create new Arabicized terms. Thanks to composition, Arabicized terms and/or words can be arranged and combined with foreign affixes or Arabic affixes can be combined with foreign words (Darwish, 2009).

Outright phonetic borrowing via transliteration is also frequently employed by Cairo ALA in its terminology work of translation and Arabicization, whether it is used separately or within a combination of methods. Given the fact that scientific and technical terms, which are communicated through their developers, are at times unfamiliar to the importer nations, new terms are, therefore, domesticated via certain techniques such as lexical borrowing (Talebinejad, Dastjerdi, \&Mahmoodi, 2012). Over the last two centuries, Indo-European languages such as English and French have been the main languages from which Arabic draws its new scientific and technical terminology. Hence, in the scientific domain, borrowing is inescapable in the translation and Arabicization process, especially when scientific and technical terms, mathematical symbols, trademarks, and proper names are concerned (Ahmed, 2011, p. 492). Accordingly, الاستعارة اللفظية[al-isti'arah al-lafdhiyah] as an Arabicization technique is inevitable, especially when scientific language is transferred from a foreign language into Arabic. However, coining native Arabicized equivalents, which rest on inherent Arabic rules, is more appropriate. Anyhow, the coinage process is a task that is fraught with difficulties because the concepts, which are embodied in most terms, are genuinely foreign. This goes in line with the arguments of a number of Arab scholars like Ya'qub, 1986; Aal, 1994; Darwish, 2009), who believe that lexical borrowing is not preferable and even too much utilization of this technique as an Arabicization method endangers the Arabic language and accelerates its foreignization.

Findings of this research paper proved that sincere and determined efforts have indeed been made by Cairo ALA (2002) to utilize native methods of Arabic word-formation processes other than direct phonetic borrowing and loan translation. Therefore, appropriate Arabicization methods and translation strategies were employed by the academy in proposing appropriate Arabicized equivalents for the English terms so as to designate an innovation or a concept embodied in these terms. Although results have triggered a clear, detectible pattern of direct transference of the English term into Arabic, Cairo ALA has in fact made extraordinary endeavours to apply appropriate coining methods of Arabicization and translation. In other words, there exists clear evidence of an internal response in the Arabic language to the lexical impact of English. It is also evident that the pressure and influence of English over Arabic have stimulated attempts to increase the lexical capacity of the Arabic language.

\section{Conclusion and Recommendations}

In conclusion, results confirmed earlier findings suggested by Arab linguists and neologizers that coinage and introduction of new words into Arabic should be carried out through productive word creation using internal resources of the Arabic language. Therefore composition and 
AWEJ for translation \& Literary Studies volume, 1 Number 2, May 2017

Translation and Arabicization Methods of English Scientific

Awang \& Salman

derivation were used by Cairo ALA in its term-making methodology. Findings revealed that this academy has adequately translated and appropriately Arabicized English scientific and technical terms. Therefore, the paper recommends that all Arabic language academies in the Arab region follow Cairo ALA's example in its terminological efforts. However, terminology work of Arabicization should be enhanced by extending the use of various methods of word-formation that are inherent in Arabic,viz. derivation, composition, compounding, analogy, metaphor so that native forms of foreign terms are coined and disseminated. As outright phonetic borrowing encourages foreignness of Arabic, the study calls for the delimitation of 'foreignization', which is regarded as a constant discouragement to the integrity of the Arabic language. Therefore, lexical borrowing as a strategy for translation and a method for Arabicization should be the translator's last resort.

\section{Acknowledgments}

The authors would like to express due thanks and gratitude to Universiti Sains Malaysia (USM), School of Humanities, represented by the Dean of the School, Professor Dr. Narimah Samat for the university fellowship grant to the second author of this paper.

\section{About the Authors:}

Dr. Rokiah Binti Awang is a lecturer in translation studies at the School of Humanities, Universiti Sains Malaysia. Her research interests include news translation, editing and assessment of translation.

Ghada Saeed Salman is a PhD candidate in translation studies at the School of Humanities, Universiti Sains Malaysia. She has worked as an instructor of translation at Al-Balqa' Applied University in Jordan.

\section{References}

Abdelhay, A.;Eljak, N.; Mugaddam, A.,\&Makoni, S. (2016). Arabicisation and the Khartoum Arabic language academy. The Journal of North African Studies, 21(5), 831-856.

Ahmed Elmgrab, R. (2011). Methods of creating and introducing new terms in Arabic: Contributions from English-Arabic translation. International Conference on Languages, Literature and Linguistics IPEDR, 26, IACSIT Press, Singapore, 491-500.

Al-Asal, M., \& Smadi, O. (2012). Arabicization and Arabic expanding techniques used in science lectures in two Arab universities. Asian Perspectives in the Arts and Humanities Journal. 2 (1), 15-38.

Al-Haq, F. \& Al-Essa, S. (2016)Arabicization of business terms from terminology planning perspective. International Journal of English Linguistics 6 (1), 150-164.

Arabic Language Academy in Cairo. Retrieved from: http://www.arabicacademy.org.eg/

Aziz, Y. (1983). Transliteration of English proper nouns into Arabic. META, 28 (1), 70-84. 
AWEJ for translation \& Literary Studies volume, 1 Number 2, May 2017

Translation and Arabicization Methods of English Scientific

Awang \& Salman

Bader, Y. (1994). Loan translations in written Jordanian news media. In Beaugrande, Robert de, Abdullah Shunnaq \& Mohamed Helmy Heliel (Eds.).Language, discourse and translation in the West and Middle East (pp. 133-140). Amsterdam: John Benjamins.

Bahumaid, S. (2010). The terminological issue in Arabic revisited: The case of discourse analysis terms. Zeitschrift fur ArabischLinguistik(Journal of Arabic Linguistics) 52, 68-83.

Bahumaid, S. (1994). Terminological Problems in Arabic. In R. De Beaugrande, Abdulla Shunnaq, \& Mohamed Helmy Heliel (Eds.). Language, discourse and translation in the West and Middle East (pp. 133-140). Amsterdam: John Benjamins.

Bielsa, E., \&Bassnett, S. (2008). Translation in global news. Oxford: Routledge.

Catford, J. (1967). Translation and language teaching. In Conseil de l'Europe.Conseil de la coopérationculturelle (Eds.).Linguistic theories and their application. AIDELA: London.

Chesterman, A., Salvador, N. G. S., \& Gambier, Y. (Eds.).(2000). Translation in context. Amsterdam: John Benjamins Publications.

Darwish, A. (2010). A journalist's guide to live direct and unbiased news translation. Melbourne: Writescope Publishers.

Darwish, A. (2009). Terminology and translation: A phonological-semantic approach to Arabic terminology. Australia: Writescope Publishers.

Darwish, A. (2006). Translating the news: Reframing constructed realities. Translation Watch Quarterly, 2 (1), 52-94.

Fraghal, M. \&Shunnaq, A. (1999).Translation with reference to English and Arabic: A practical guide. Irbid, Jordan: Dar Al-Hilal for Translation.

Gambier, Y. (2006).Transformations in International News.In Conwa, K. \&Bassnett, S. (Eds.).Translation in Global New Proceedings of the conference held at the University of Warwick 23 June 2006. The Centre for Translation and Comparative Cultural Studies University of Warwick: U.K.

Hawamdeh, F. (2004). Term planning: A case study of weather terms.(Unpublished Master's thesis). Yarmouk University, Irbid, Jordan.

Khulusi, S. (1982) Fann at-Tarjama fi Daw? ad-Diraasaat al- Muqaarana. Baghdad: DaaralShuPuun al-Thaqaafiyya.

King Faisal International Prize KFIP (2013). Retrieved from http://kfip.org/arabic-languageacademy-in-cairo-2/

Pinchuck, I. (1977). Scientific and technical translation. London: Andre Deutsch.

Talebinejad, M. R., Dastjerdi, H. V., \& Mahmoodi, R. (2012). Barriers to technical terms in translation: Borrowings or neologisms. Terminology, 18 (2), 167-187.

Vinay, J. P., \&Darbelnet, J. (1995).Comparative stylistics of French and English: A methodology for translation (J. C. Sager \& M. J. Hamel, Trans.) Amsterdam, PA: John Benjamins.

Vybíralová, H. (2012). Journalistic translation in the selected Czech press.(Unpublished Master's thesis). Masaryk University, Czech. 